Pak. j. sci. ind. res. Ser. B: bio. sci. 2021 64B(3) 251-255

\title{
Antimicrobial Study of Selected Medicinal Plants (Datura stramonium L. and Hippophae rhamnoides L.) of Hunza Valley, Gilgit-Baltistan
}

\author{
Qamar Abbasa, Shahina Batool ${ }^{\mathrm{a}}$, Sher Wali Khan ${ }^{\mathrm{a}}$, Azhar Hussain ${ }^{\mathrm{b}}$, Saif Ud Din ${ }^{\mathrm{c} *}$, \\ Maisoor Ahmed Nafees ${ }^{a}$, Shamsher Ali ${ }^{d}$, Muhmmad Ali Faizi ${ }^{\mathrm{e}}$ and Asad ullah ${ }^{\mathrm{f}}$ \\ ${ }^{a}$ Department of Biological Sciences, Karakoram International University, Gilgit-Baltistan, Pakistan \\ ${ }^{b}$ Department of Agriculture and Food Technology, Karakoram International University, Gilgit-Baltistan, Pakistan \\ 'Department of Environmental Sciences, Karakoram International University, Gilgit-Baltistan, Pakistan \\ ${ }^{\mathrm{d}}$ Department of Chemistry, Karakoram International University, Gilgit-Baltistan, Pakistan \\ ${ }^{\mathrm{e}}$ Non-Timber Forest Product, Project Forest Department, Gilgit-Baltistan, Pakistan \\ ${ }^{\mathrm{f}}$ Centre of Plant Biodiversity, University of Peshawar, Peshawar, KPK, Pakistan
}

(received April 4, 2019; revised July 31, 2019; accepted August 2, 2019)

\begin{abstract}
The adverse environmental and human health impact of chemical use against micro-organism is profoundly increased. For this motive, substitute methods to minimize chemicals are being developed. One of the effective methods is use plant extracts which having natural antimicrobial properties. The aim of this study was to evaluate ethanolic extract of Datura stramonium L. (leaves) and Hippophae rhamnoides L. (fruits) against the selected micro-organisms. Results revealed that mean zone of inhibition for bacterial species ranged from $23 \pm 0.72$ to $27 \pm 1.24 \mathrm{~mm}$ in case of Hippophae rhamnoides and from $21 \pm 0.79$ to $30 \pm 1.06 \mathrm{~mm}$ in case of $D$. stramonium leaves respectively. For antifungal activity, the inhibition zone ranges from $39.42 \pm 1.07$ to $47.22 \pm 2.11 \mathrm{~mm}$ in case of $D$. stramonium and from $38.42 \pm 1.19$ to $48.46 \pm 2.32$ $\mathrm{mm}$ in case of $H$. rhamnoides. However, sensitivity reaction of bacterial and fungal species against each plant extract was also differential. D. stramonium showed highest toxic effect against $E$. coli $(30 \pm 1.06$ $\mathrm{mm})$ ) and Aspergillus flavus $(47.22 \pm 2.11 \mathrm{~mm})$. Whereas, H. rahmnoides showed highest zone of inhibition against bacterial species (B. subtilis $27 \pm 1.24 \mathrm{~mm}$ ) and fungal species (R. stolonifer $48.46 \pm 2.32 \mathrm{~mm}$ ). Both plant extract exhibited antimicrobial properties, which could be used against micro-organisms.
\end{abstract}

Keywords: antimicrobial, inhibition zone, H. rhamnoides, D. stramonium, Gilgit-Baltistan Pakistan

\section{Introduction}

Medicinal plants are the easiest and cheapest mode of medication in rural communities. Ethno botany is the study of the relationship between people and plants with particular emphasis on indigenous cultures. According to World Health Organization (WHO) roughly $65-80 \%$ of the world population in developing nations depends mainly on plants for their primary health care due to scarcity and unavailability of modern medicines (Awoyemi et al., 2012). Medicinal plants are important source of antimicrobial compounds. Many infectious diseases are being treated by using medicinally important plant extracts, as they contain a potential microbial activity. Traditionally thousands of medicinal plants are used by people and these are explored for different bioactive chemical compounds as well as their antimicrobial activities (Rice-Evans et al., 1997), and thousands of plants are still unexplored and need to be explored in future (Aberoumand et al., 2010). The

*Author for correspondence; E-mail: gltsaifuddin@gmail.com examination of different medicinally important plants for bioactive substances and therapeutically properties were conducted and these studies revealed that most of the plants have antimicrobial properties (Ahsan et al., 2009). Infectious diseases have claimed lives of millions throughout the world, during the past few decades (Sharma et al., 2013). To treat such diseases, modern medicinal drugs are facing challenges to cure perfectly due to side effects and the adaptation of many pathogens for survival in host. Many researches have been conducted in the search for medicinal plants that have improved antimicrobial effects against human and pathogens (Kumar et al., 2007).

\section{Material and Methods}

Collection of plants. This study was carried out in the Department of Biological Sciences Karakoram International University Gilgit during the year 201718 , to determine antimicrobial properties of plants. Two plant D. stramonium (Datura) and its fresh leaves 
and $H$. rhamnoides (Sea buckthorn) and its fruits were collected from different localities of district Hunza Gilgit-Baltistan Pakistan. These plants were primarily identified taxonomically with the help of the flora of Pakistan. (Fig. 1).

Preparation of extract. Sea buckthorn fruits were collected and allowed to dry in the shade. Dried berries of sea buckthorn were crushed into fine powder using grinder and stored until use. Whereas, D. stramonium leaves were cleaned thoroughly with running tap water and dried in sunlight. Then the leaves were grounded into a fine powder. About $195 \mathrm{~g}$ of sea buckthorn berries powder and $60 \mathrm{~g}$ of $D$. stramonium leaves powder were soaked in $300 \mathrm{~mL}-500 \mathrm{~mL}$ respectively in the $90 \%$ methanolic solvent and $10 \%$ distilled water (9:1) for $72 \mathrm{~h}$ ( 3 days). This process was repeated two times and finally $100 \%$ methanol used for soaking. Then the soaked samples were filtered in different beakers by using filter papers, then the filtrates were evaporated in Rotary Evapourator to obtain the methanolic extract of both samples. This methanolic extract was used to check the antimicrobial bioassay screening.

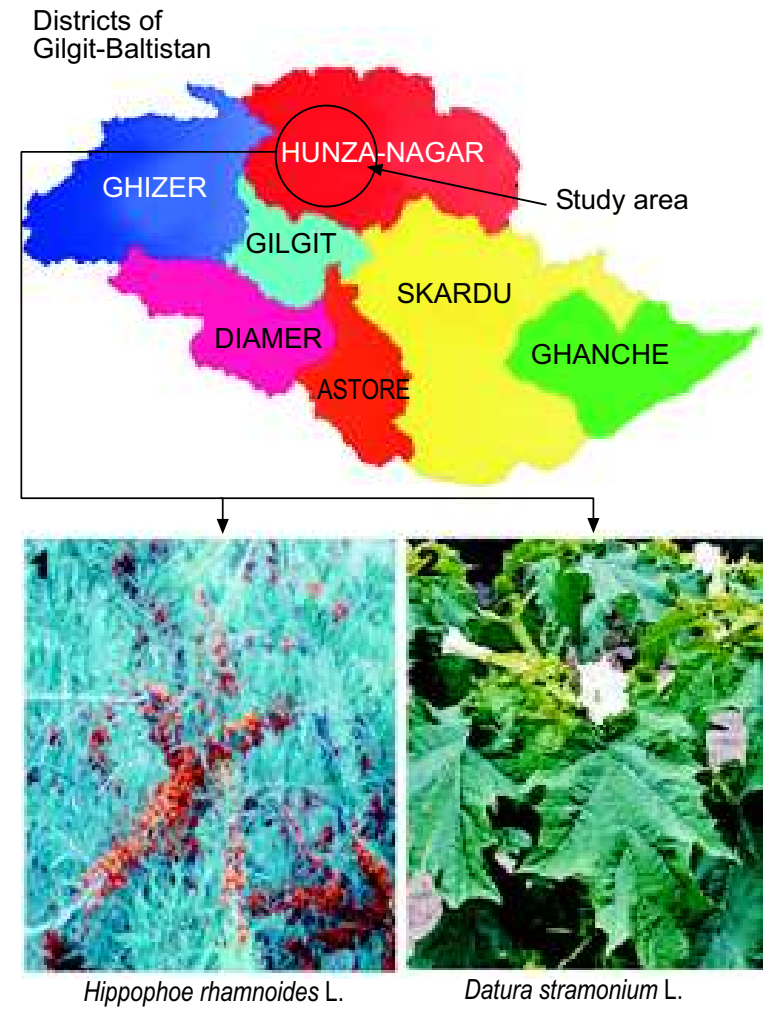

Fig. 1. Map of study area.
Isolation of micro-organisms. Different human faces and soil samples were used to isolate targeted microorganisms by serial dilution techniques. In serial dilutions $1 \mathrm{~g}$ of sample was aseptically transferred into $9 \mathrm{~mL}$ of distilled water and homogenized by vortex. Following serial dilutions were made up to $10^{4}$ for isolation of micro-organisms. For isolation of bacterial species nutrient agar was used, whereas for fungal species potato dextrose agar. Identification of bacterial species was identified as describes in WHO Manual, 1987 and fungal species (Nagamani et al., 2006; Gilman, 1957). Finally three bacterial species (Escherichia coli, Staphylococcus aureus and Bacillus subtilis) and three fungal species (Fusarium spp., Aspergillus flavus, Penicillium spp. and Rhizopus stolonifer). Antimicrobial bioassays for bacterial were performing by mean of disc diffusion method (Boussaada et al., 2008; Basu et al., 2005; Nostro et al., 2000). For fungal species food poisoned technique was applied (Mishra and Tiwari, 1992). The inhibition zones were calculated in $\mathrm{mm}$ (Daniyan and Mahammad, 2008). The efficiency percentage of inhibition zone percentage $(\mathrm{mm})$ was calculated by using this formula:

Zone of inhibition $\%=\frac{\text { CGC }- \text { CGT }}{\mathrm{CGC}} \times 100$

$\mathrm{CGC}=$ Colony growth in control; $\mathrm{CGT}=$ Colony growth in treatment.

\section{Results and Discussion}

Plant wealth is treasure of nature and medicinal plants application for medications are very common among the mountainous communities of the world. The antimicrobial activity of medicinally important plants was determined by measuring to their inhibition zone against different strains of human pathogenic bacteria and fungi. For bacterial species Datura stramonium showed mean inhibition zone ranges between $30 \pm 1.06$ to $-30 \pm 1.06 \mathrm{~mm}$, while in Hippophae rhamnoides inhibition zone varied from 23-27 mm (Fig 2). D. stramonium was effective against $E$. coli followed by $S$. aureus, while $H$. rahmnoides showed slightly higher antibacterial properties against $B$. subtilis and $S$. aureus (Table 1).

Benli et al. (2007) described that methanol solution of Artemisia dracunculus L. revealed superior results as compare to chloroform and acetone extracts. Its methanol extract was found active after being tested with dual strains of E. coli and three other bacterial types, however 


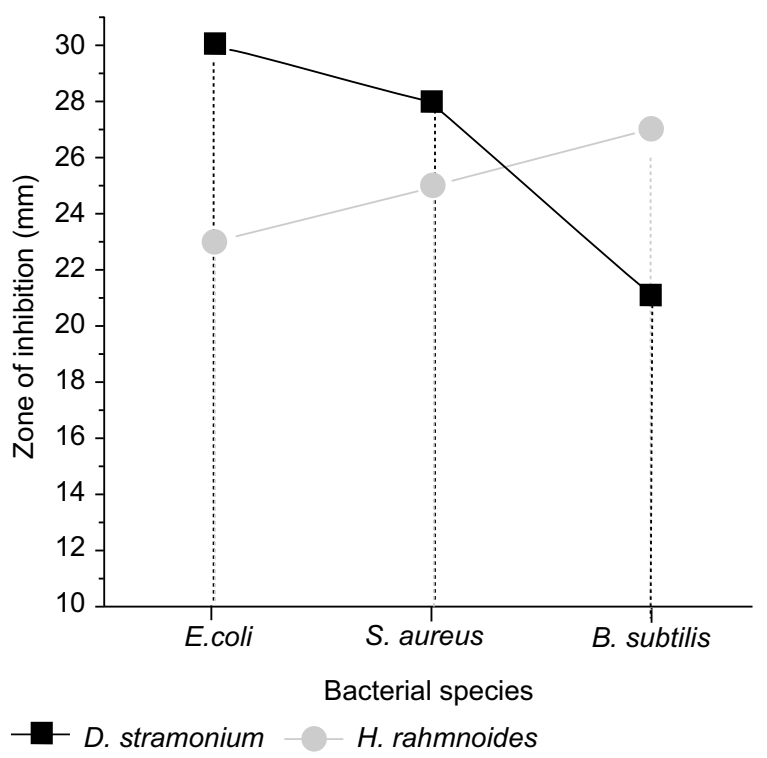

Fig. 2. Shows the inhibition zone of different strains of bacteria.

Table 1. Antibacterial activity of $D$. stramonium and H. rhamnoides

\begin{tabular}{llll}
\hline \hline Bacteria & $\begin{array}{l}\text { Gram } \\
\text { morphologies }\end{array}$ & $\begin{array}{l}\text { Inhibition }(\mathrm{mm}) \\
\text { zone of } 5 \% \mathrm{D} .\end{array}$ & $\begin{array}{l}\text { Inhibition }(\mathrm{mm}) \\
\text { zone of } 5 \% \mathrm{H} . \\
\text { stramonium }\end{array}$ \\
\hline E. coli & Gram -ve & $30 \pm 1.06$ & $23 \pm 0.72$ \\
S. aureus & Gram +ve & $28 \pm 1.76$ & $25 \pm 1.14$ \\
B. subtilis & Gram +ve & $21 \pm 0.79$ & $27 \pm 1.24$ \\
\hline \hline
\end{tabular}

it was found ineffective against $S$. pyogenes and $S$. aureus. In the present research study, the methanolic extract of $D$. stramonium leaves showed a significant effect against $E$. coli with inhibition zone of $30 \mathrm{~mm}, S$. aureus with zone of inhibition $28 \mathrm{~mm}$ and it showed a minimum inhibition zone of $21 \mathrm{~mm}$ against $B$. subtilis. Similarly, the methanolic extract of sea buckthorn berries recorded $27 \mathrm{~mm}$ with maximum inhibition zone against B. subtilis, $25 \mathrm{~mm}$ inhibition zone against $S$. aureus, and $23 \mathrm{~mm}$ inhibition zone against $E$. coli. In some recent researches conducted to evaluate the efficacy of Artemisia nilagirica different extract against 15 bacterial strains and the results were highly promising (Ahameethunisa and Hopper, 2010).

In one more investigation, diverse classes of the genus Ferula (Apiaceae) has revealed flexible antibacterial outcomes. The chloroform extract of Ferula persica roots was effective against $E$. coli, K. ponumoniae, $S$. typhi, S. aureus and S. epidermilis. The active compound was identified as umbelliprenin (Shahverdi et al., 2005). Ferula rigidula has displayed a wide range of activities (Sener et al., 1998). Root volatile oil of Ferula hermonis has also demonstrated the highest antibacterial agent (Hilan et al., 2007). Seddik (2010) stated that ethyl acetate and chloroform extracts of Artemisia herbaalba Asso, indicated outstanding activity to counter bacteria. These extracts contain large amount of phenolic compounds. Antifungal activity of extracts against selected fungal species was evaluated by food poison techniques. The data showed that the tested extracts exhibited varied degree of zone of inhibition against the fungi. Mean zone of inhibition percentage of fungal species against extracts have been presented in the Fig. 3 and Table 2.

Range of inhibition zone ( $\mathrm{mm}$ ) was $39.42 \pm 1.07$ to $44.64 \pm 1.90$ in D. stramonium, $38.42 \pm 1.19$ to $48.46 \pm 2.32$ $\mathrm{mm}$ in $H$. rahmnoides and $D$. stramonium effectively

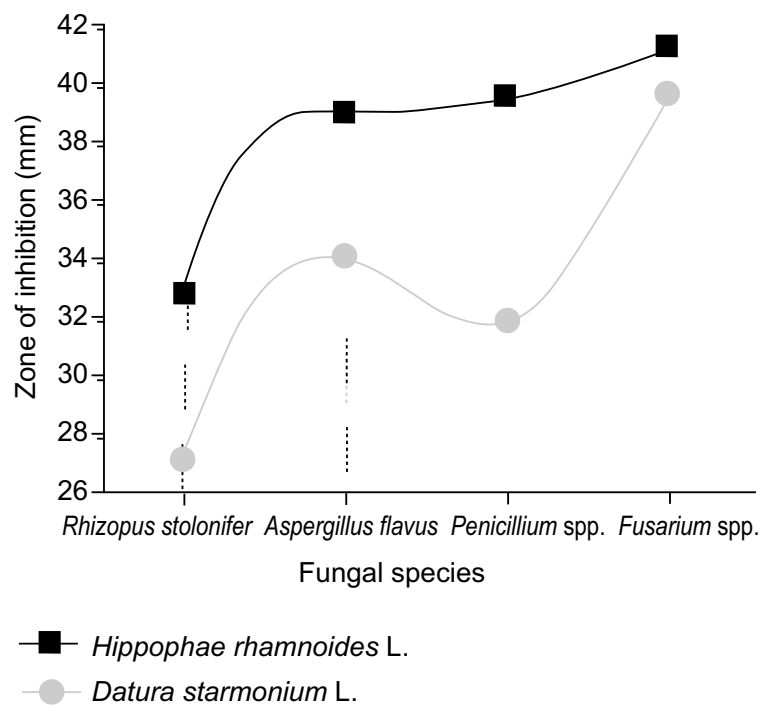

Fig. 3. Shows the efficiency of different strains of fungus.

Table 2. Antifungal activity of $D$. stramonium and $H$. rahmnoides

\begin{tabular}{llll}
\hline \hline Fungus & Control & $\begin{array}{l}\text { Average inhibition } \\
(\mathrm{mm}) \text { zone of 5\% }\end{array}$ & $\begin{array}{l}\text { Average inhibition } \\
(\mathrm{mm}) \text { zone of 5\% }\end{array}$ \\
& & D. stramonium & H. rahmnoides \\
\hline R. stolonifer & $66.42 \pm 2.01$ & $44.64 \pm 1.90$ & $48.46 \pm 2.32$ \\
P. spp. & $68.44 \pm 1.09$ & $41.42 \pm 1.03$ & $46.66 \pm 1.90$ \\
A. flavus & $71.56 \pm 4.31$ & $47.22 \pm 2.11$ & $43.66 \pm 1.99$ \\
Fusarium & $65.22 \pm 3.17$ & $39.42 \pm 1.07$ & $38.42 \pm 1.19$ \\
spp. & & & \\
\hline \hline
\end{tabular}


inhibited mycelial growth of A. flavus (47.22 \pm 2.11$)$ followed $R$. stolonifer $(44.64 \pm 1.90 \mathrm{~mm})$ whereas, least zone of inhibition was recorded in Fusarium spp. $(39.42 \pm 1.07 \mathrm{~mm})$. The range of zone of inhibition of H. rahmnoides was recorded $23 \pm 0.72$ to $27 \pm 1.24$. Highest zone of inhibition was found in fungal species R. stolonifer $(48.46 \pm 2.32 \mathrm{~mm})$ followed by Penecillium spp. $(46.66 \pm 1.90 \mathrm{~mm})$, while least in Fusarium spp. $(38.42 \pm 1.19 \mathrm{~mm})$. The methanol leaf extracts of numerous plants exhibited improved antifungal activity later treated with Aspergillus flavus, Dreschlera turcica and Fusarium verticillioides have been described (Mahesh and Satish, 2008). Reports of antimicrobial activity or earlier investigations have verified antifungal properties of diverse varieties of extracts (Zhu et al., 2005; Guo et al., 1997; Wilson et al., 1997).

Mann et al. (2008) studied Anogeissus leiocarpus and Terminalia avicennioides, ethanolic extracts were more efficient than methanolic and all other extracts against fungi. In a current research the methanol extract of $D$. stramonium leaf demonstrated that it has highest antifungal activity against Penicillin spp. with $39.47 \%$ zone of inhibition, $39.55 \%$ inhibition zone against fusarium, 34.79\% inhibition against $A$. flavus and with minimum zone of inhibition against $R$. stolonifera. Similarly, the methanolic extract of sea buckthorn berries recorded $41.11 \%$ with maximum inhibition zone against fusarium, 38.99\% inhibition zone against A. flavus, $31.82 \%$ zone of inhibition against $P$. spp., and $27.04 \%$ (minimum) zone of inhibition against $R$. stolonifer. Similar results were found by Manoorkar and Gachande (2014) and Saeed and Tariq (2005). Another supported our results that the maximum antifungal activity of Mentha flowers in contrast with that of the further particular plant portions is credited to the most effective acetone, methanol and ethanol extracted metabolites when treated with $F$. moniliforme (Yazgi et al., 2015).

\section{Conclusion}

In this review, extracts of two plants were tested for antimicrobial activities against three strains of bacteria i.e. E.coli, S. aureus, B. subtilis and four strains of fungus i.e. Fusarium, A. flavus, $P$. spp., R. stolonifera. The results of the above investigation clearly indicated that the antimicrobial activities of $D$. stramonium showed a significant inhibition of all tested bacterial and fungal pathogens as compare to sea buckhorn. It was concluded that $D$. stramonium leaves and $H$. rhamnoides berries exhibited antibacterial and antifungal properties against different strains of bacteria and fungi. Further studies are required to isolate the targeted secondary metabolites exist in these potential plants.

Conflict of Interest. The authors declare no conflict of interest.

\section{References}

Aberoumand, A., Deokule, S., Ali, A. 2010. Preliminary assessment of nutritional value of polly dwarf (Alocacia indica S.), a plant food in India. Pakistan Journal of Agricultural Sciences, 47: 136-139.

Ahameethunisa, A.R., Hopper, W. 2010. Antibacterial activity of Artemisia nilagirica leaf extracts against clinical and phytopathogenic bacteria. BMC Complementary and Alternative Medicine, 10: 6.

Ahsan, M., Islam, K., Haque, M., Mossaddik, M. 2009. In vitro antibacterial screening and toxicity study of some different medicinal plants. World Journal of Agricultural Sciences, 5: 617-621.

Awoyemi, O., Abdulkarim, I., Ewa, E., Aduloju, A. 2012. Ethnobotanical assessment of herbal plants in south-western Nigeria. Academic Research International, 2: 50.

Basu, S., Ghosh, A., Hazra, B. 2005. Evaluation of the antibacterial activity of Ventilago madraspatana Gaertn., Rubia cordifolia Linn. and Lantana camara Linn, Isolation of Emodin and Physcion as active antibacterial agents. Phytotherapy Research, 19: 888-894.

Benli, M., Kaya, I., Yigit, N. 2007. Screening antimicrobial activity of various extracts of Artemisia dracunculus L. Cell Biochemistry and Function, 25: 681-686.

Boussaada, O., Ammar, S., Saidana, D., Chriaa, J., Chraif, I., Daami, M., Helal, A.N., Mighri, Z. 2008. Chemical composition and antimicrobial activity of volatile components from capitula and aerial parts of Rhaponticum acaule DC growing wild in Tunisia. Microbiological Research, 163: 87-95.

Daniyan, S.Y., Muhammad, H.B. 2008. Evaluation of the antimicrobial activities and phytochemical properties of extracts of Tamaridus indica against some diseases causing bacteria. African Journal of Biotechnology, 7: 2451-2453.

Gilman, J.C. 1957. A Manual of Soil Fungi Revised, 2nd edition, 220 pp, Oxford and IBH Publishing Co.

Guo, B.Z., Chen, Z.Y., Brown, R.L., Lax, A.R., Cleveland, T.E., Russin, J.S., Mehta, A.D., Selitrennikoff, C.P., Widstrom, N.W. 1997. 
Germination induces accumulation of specific proteins and antifungal activities in corn kernels. Phytopathology, 87: 1174-1178.

Hilan, C., Sfeir, R., Hage, R.E., Jawich, D., Frem, M.E., Jawhar, K. 2007. Evaluation of the antibacterial activities of Ferula hermonis (BOISS.). Lebanese Science Journal, 8: 135-151.

Kumar, B., Vijayakumar, M., Govindarajan, R., Pushpangadan, P. 2007. Ethno-pharmacological approaches to wound healing - exploring medicinal plants of India. Journal of Ethnopharmacology, 114: 103-113.

Mahesh, B., Satish, S. 2008. Antimicrobial activity of some important medicinal plant against plant and human pathogens. World Journal of Agricultural Sciences, 4: 839-843.

Mann, A., Banso, A., Clifford, L.C. 2008. An antifungal property of crude plant extracts from Anogeissus leiocarpus and Terminalia avicennioides. Tanzania Journal of Health Research, 10: 34-38.

Manoorkar, V.B., Gachande, B.D. 2014. Evaluation of antifungal activity of some medicinal plant extracts against some storage seed-borne fungi of Groundnut. Science Research Reporter, 4: 67-70.

Mishra, M., Tiwari, S.N. 1992. Toxicity of Polyalthia longifolia against fungal pathogens of rice. Indian Phytopathology, 49: 56-61.

Nagamani, A., Kunwar, I.K., Manoharachary, C. 2006. Hand Book of Soil Fungi, I.K. International Private Limited.

Nostro, A., Germano, M.P., Angelo, V.D., Marino, A., Cannatelli, M.A. 2000. Extraction methods and bio-autography for evaluation of medicinal plant antimicrobial activity. Letters in Applied Microbiology, 30: 379-385.

Rice-evans, C., Miller, N., Paganga, G. 1997. Antioxidant properties of phenolic compounds. Trends in Plant
Science, 2: 152-159.

Saeed, S., Tariq, P. 2005. Antibacterial activities of Mentha piperita, Pisum sativum and Momordica charantia. Pakistan Journal of Botany, 37: 9971001.

Shahverdi, A.R., Iranshahi, M., Mirjani, R., Jamalifar, H., Amin, G., Shafie, A. 2005. Bioassay-guided isolation and identification of an antibacterial compound from Ferula persica Var. Persica roots. DARU Journal of Pharmaceutical Sciences, 13: 17-19.

Seddik, K., Nadjet, I., Abderrahmane, B., Daoud, H., Lekhmici, A. 2010. Antioxidant and antibacterial activities of extracts from Artemisia herba-alba Asso., leaves and some phenolic compounds. Journal of Medicinal Plants Research, 4: 1273280.

Sener, B., Bingo, F., Erdogan, I., Bowers, W.S., Evans, P.H. 1998. Biological activities of some Turkish medicinal plants. Pure and Applied Chemistry, 70: 403-406.

Sharma, R., Sharma, P., Yadav, A. 2013. Antimicrobial screening of sequential extracts of Datura stramonium L. International Journal of Pharmacy and Pharmaceutical Sciences, 5: 401-404.

Wilson, C.L., Solar, J.M., El Ghaouth, A., Wisniewski, M.E. 1997. Rapid evaluation of plant extracts and essential oils for antifungal activity against Botrytis cinerea. Plant Disease, 81: 204-210.

Yazgi, M., Awad, D., Jreikous, B. 2015. Screening of the antifungal activity of plant Mentha longifolia crude extracts against two fungi Alternaria citri and Fusarium moniliforme. Journal of Entomology and Zoology Studies, 3: 59-364.

Zhu, X.F., Zhang, H.X., Lo, R. 2005. Antifungal activity of Cynara scolymus L. extracts. Fitoterapia, 76: 108-111. 